\title{
都市・農村交流による農産物流通の展開方向
}

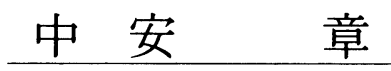

\section{Directions of Farm Products Marketing by Rural Tourism}

\author{
Akira Nakayasu (Ehime University)
}

The purpose of this paper is to clarlify the directions of farm products marketing with interactions between urban and rural residents, espscially farmers' rural markets. Major results are described that follows:

(1) Farmers' rural markets are increasing recently. That backgrounds are the increasing needs of urban residents, the changes of the distribution environmrnts, the changes of rural residents.

(2) The markets have the following significances: the acquirement of new marketing channels, to widen women's spheres of activity, the reductions of mar- keting costs, to get valuable information between urban and rural residents, and the far-reaching effects to the other industries in rural area.

(3) But they have two problems: As farm products are strong seasonal goods, to stock everything in all seasons is difficult. Recently the competition among the markets has become strengthened.

(4) Farmers' rural markets will be increasing from now on. In order to reassess the value of rural resources, it will be important to promote the connection among the other industries in rural area.

\section{1.はじめに}

21世紀を目前として，わが国の農産物流通は大きな 曲り角にさしかかっている. 食糧法施行後の米流通の 変化は大きい，卸売市場流通主体とされてきた青果物 の流通にも多様な流通チャネルが登場, 形成されてい る. 小売段階でのスーパーマーケットのシェア払大は 進み, 八百屋等の専門小売店は大きく減少している. しかし，人件費，施設・設備投資費の増大のため， スーパーマーケットの経営も敛しいものとなってい る. 農産物価格についてみると, スーパーマーケット が専門小売店よりも安いとは言い難い。また，仕入れ 価格を引き下げるために, 輸入農産物・食料品の販売 が増加した。

また座長解題でもあるよらに，近年の都市・農村交 流に対する都市消費者のニーズが扗大している．同時 に従来は組織員としての参加から個別参加型交流の進 展がみられるなど, 消費者の行動範囲も払大してい る. 食料品の安全性を求める消費者が自ら農村部に誕 生する農産物直売所へ買物にでかける。 その意味でる 都市・農村交流は新しい段階に入ったといえる．近年 の都市・農村交流による農産物流通の動き，とくに農 産物直売所の増加傾向は域内あるいは地場流通再編の
過程と考える.

本報告では，このような視点の下で，都市・農村交 流による新たな農産物流通の動きを，とくに従来の卸 売市場流通, 産直では得られなかった生産者および消 費者のベネフィットの追求として捉らえる. 課題とし て, 都市・農村交流による農産物流通の動向, とくに 農産物直売所等の増加の実態と背景, 生産者及び消費 者からみた意義, 問題点, 今後の展開方向を明らかに する.なお，ここで取り上げる農産物直売所は，常設 ・有人店舗で, 生産者が自ら值付けした商品を持込 み，消費者に小売する場所としだ).

\section{2. 都市・農村交流による農産物流通, 産直活 動}

産直とは，産地（生産者）と消費者とを結んで生産 物が直接に流れることを意味するが，産地直送，産地 直販，産地直結に示されるよらに，その活動内容によ る意味合いに差が生ずる、すなわち，そこで実現する のが，モノの流れ，カネの流れに重点を沶いたもの か, ヒトの交流を重視するかによるものと考えられ る.

農協と生協のような協同組合間での産直事業, 活動 に対しては, 岡部守氏は事業論, 運動論の 2 つのタイ 
プの産直活動を考えていた22.

これらの協同組合間での産直事業・活動は, 高度経 済成長期途中から登場する。大都市に形成されていた 生活協同組合は，1960年代後半以降～1970年代に地方 中核都市を中心に全国的に形成されるようになった。 設立当初は周辺農村部との産直事業が展開されるが, 組織の扗大に伴い, 全国的な産直を行ら遠隔産地への 集中が進んだ.

しかし1980年代の低成長期に入ると，高度経済成長 期には安価に, 安定的に農産物が供給されることを中 心に望んでいた消費者も，生活にゆとりができ，同時 に食料の安全性等に関心が強くなってきた．都市消費 者の土地，住宅への執着は強く，また，自然を求める 動き，教育への関心も強くなっている．都市消費者は 食料・農業・農家に対してその重要性, 苦労を認め, 自らも子供の教育や食料品の安全性を求めている，産 直や市民農園等を通じた交流を望んでいる。すなわ ち, 複雑化する流通経路の中でその商品である農産物 の生産者の顔を知りたいとの願望である．生協等の組 織に対する全面依存から個別参加型の交流が増加して くる.

したがって産直も多様化し，新たな段階へと入る. その中で，モノ・カネの流れよりも，それらを媒介と したヒトの交流に主眼が扣かれ始める。すなわち，ふ るさと産直運動として捉らえられる動きである.

食の多様化, ファッション化は, 新たな外食産業, 流通業者を生み出した. グルメブームの到来は, 食の 国際化をむ追及するようになる反面, 消費者の安全食 品志向, 健康食品志向, ふるさと志向, 本物志向を上 昇させてくる．ふるさと食品の登場である．これは， デパート，スーパーの 1 企画， 1 コーナーにとどまら ず，2つの新たな動きを登場させる。

第 1 は，宅配便・郵パックによる小規模物流の急増 である，運送会社，流通業者が乗出し（宅急便）, 郵 便局が追走（郵便小包）する形で展開する.

その背景として, 輸送技術の発達によって全国的な 広域卸売市場流通が進むが，同時に情報技術の発達と によって生鮮品目の産直を可能にしたことがあげられ る. また，宅配便が急増するなかで JR（国鉄）貨物， 手小荷物や郵便小包の取扱数は減少している.JR は 貨物部門の縮小へと転換するが，郵便小包は新たな展 開を目論む.すなわち，消費者のふるさと志向から登 場したふるさと食品をふるさと小包として巻き返しを 図ったのである。

第 2 は, 一村一品運動からふるさと産直運動への展
開である．農村の過疎化，高龄化をくい止める方策と して，扣らが村の特産品＝ふるさと食品として付加価 值を高めて販売する．自治体の支援によるむら抗こし でもあり, 都市・農村交流活動等を通じて販路を払大 していった.

これは，都市と農村の交流型であるふるさと産直運 動へと展開してきた，その形態として，(1)地域特産物 の都市住民への直送, (2)果樹, 肉牛等のオーナーシス テム，(3)特別村民制，(4)農産物直売所等があげられ る.とくに近年, 農産物直売所を介した地域の農産物 あるいはその加工品の販売が盛んになっている．生産 農家にとって，新しい販売チャネルの一つとして無視 できない存在となりつつある。また，生産者と消費者 の交流の場として直売を評価する動きが強まった.

\section{3. 農産物直売所設置の動きとその背景}

農産物の直売は, 都市部を中心に古くから存在する 流通形態である．伝統的な朝市や観光地近くでの青空 市等に扣ける青果物の販売, 卸売市場出荷を指向しな い都市農家あるいは高龄者農家による庭先販売，無人 市等の個別的な直売は, 形態を変えながら現在でも存 続している.

しかし1980年代に入り，青空市，直売所，ふれあい 市等, 新たな農産物直売所が全国各地で見られるよう になった，その設置に打いては，集落組織，生活改善 グループ，農協婦人部等を母体とした農家組織によっ て発足・運営されていた例が多い，設立当初は，農家 の小規模栽培野菜の余㮃分あるいは規格外品を出荷 し, 参加農家による当番制といった運営方法が取ら れ，小規模かつ簡易的なシステムが大半であった。 た当時の組織は少人数で構成されることが多く，構成 員も年齢（高年龄者）, 性別（女性）, 出荷行動（規格 外品中心）等類似した，同質性の高い組織であった．

この農産物直売所も近年変化してきた. 1990年代に なって, 直売所そのものの増加と規模拡大がみられ, 同時に各直売所への参加農家数の増加と販売高増加で ある. その結果，多様な形態の直売所が誕生すると同 時に，同質性が希薄になる傾向も見られる.

農産物直売施設が設立, 増加した要因, 背景として 以下の諸点があげられる.

第 1 に，都市消費者側の二ーズの増大である.

(1)前述したふるさと産直運動の過程で, 都市・農村 交流事業が進展し, 多くの組織, 個人参加型で農村部 に出かけることが多くなった.

(2)消費者の健康食品志向，ふるさと志向，本物志向 
が身近なところにある直売所に向けられるようになっ たことである.

第 2 亿，生産者サイドの状況変化である.

(3)水田転作や米価格の低迷伴伴野菜生産の増加. 水田転作政策によって各地で野菜産地化が進められた が，1980年代には卸売市場での野菜供給過剩問題が発 生し, 十分な定着が見られなかった. しかし野菜生産 への関心を高めるとともに, 余㮃野菜の販路獲得とし て直売活動の進展させたと考えられる.

(4)観光農業等の他の都市・農村交流活動の販売の場 を必要とした。

(5)農家女性グループ等による農産物自給運動の展開 も重要な要因である.農家女性が自らの食生活見直し と自給運動へ取り組む結果, 余剩野菜の販売や地元産 品を利用した加工食品の開発といった取組みから直売 活動へと展開していったといえる.

第 3 に，流通環境の変化である.

(6)交通アクセス，モータリゼーションの進展とリ ピーターの形成. 中山間地域に打ける道路網の整備と 乗用車普及率の上昇により, 都市や平野部の住民から 中山間地域へのアクセスは相対的に改善された，農村 や地域特産品に関心を持つ都市消費者が絽り返し訪れ ることが容易になり,リピーターが形成されるよらに なった。

(7)自治体主導による特産品センター, 農林産物加工 場, 宿泊施設とセットした直売所設置が増加した. 中 山間地域では, ふるさと創生資金の利用によるものが 多いため，1990年以降に増加している.

(8)域内・地場流通の中心的な流通主体であった零細 地方卸売市場と食品小売業者の衰退によって，新たな
流通施設として直売所等の必要性が強まった.

\section{4. 全国及び愛媛県における農産物産直, 直売 所の取り組み}

（1）全国における農産物産直, 直売所の取り組み

これら農産物産直, 直売所の事例研究は多く見られ るが, 全国的に産直件数, 直売所設置数等を調査, 把 握したものは極めて少ない，そのなかで多く引用され るのが，1995年に行われた農林水産省婦人・生活課の 調査結果「全国朝市実施状況一覧表」である。そこで は, 施設の設置市町村数 3,242 , 設置数 2,704 件となっ ている.

これに対して，1997年度に埼玉県が全国の都道府県 に依頼し, 農産物産直, 直売所等の取り組み実態を調 查している.この調査結果によると, 農産物産直, 直 売所の実施件数は全国で11,356件となっている. 形態 別に2ると有人直売所が最も多く，3,671件と全体の 3 分の 1 を占めており, 全国の市町村数を上回る数と なっている。これに無人直売所, 朝市・夕市を加えた 有店舗形態のものが7, 465件であり, 前述の農水省の 朝市調査と比較して取り組みが進んでいることがわか る.

取扱っている品目は多種多様であるが，野菜類が多 い(65.1\%) のが特徵である. 次いで果樹 $(30.7 \%)$, 加工品 $(22.2 \%)$, 花・植木 $(20.4 \%)$ 等となってい る(表 1 ).

有人直売所についてみると，やはり野菜類を扱ら施 設が多い。またその経営主体は生活改善グループ等を 中心とした小規模農家生産者グループが多いが，農協 や市町村が経営, 運営している施設も増えている.

表 1. 形態別にみた農産物産地直売の実態（全国, 1997年度）

\begin{tabular}{|c|c|c|c|c|c|c|c|c|c|c|}
\hline \multirow{2}{*}{$\begin{array}{ll} & \text { 調査区分 } \\
\text { 形態 } & \\
\end{array}$} & \multirow{2}{*}{ 実施件数 } & \multicolumn{9}{|c|}{ 取扱っている品目（重複回答あり） } \\
\hline & & 野 菜 & 果 樹 & 花植木 & 畜産物 & 特産物 & 加工品 & 林産物 & 米 & その他 \\
\hline 有店舗 & 7,465 & 5,205 & 2,287 & 2,009 & 356 & 737 & 2,076 & 992 & 231 & 674 \\
\hline 有人直売所 & 3,671 & 2,382 & 1,407 & 1,000 & 219 & 583 & 1,329 & 623 & 188 & 360 \\
\hline 無人直売所 & 1,968 & 1,593 & 383 & 401 & 73 & 47 & 213 & 208 & 6 & 150 \\
\hline 朝市・夕市 & 1,826 & 1,230 & 497 & 608 & 64 & 107 & 534 & 161 & 37 & 164 \\
\hline 無店舗1) & 2,615 & 1,647 & 850 & 254 & 95 & 110 & 87 & 62 & 12 & 53 \\
\hline 契約2) & 537 & 321 & 74 & 25 & 19 & 31 & 80 & 37 & 29 & 31 \\
\hline 宅配·宅送販売 & 739 & 224 & 272 & 27 & 70 & 109 & 275 & 79 & 54 & 78 \\
\hline 合 計 & 11,356 & 7,397 & 3,483 & 2,315 & 540 & 987 & 2,518 & 1,170 & 326 & 836 \\
\hline 取扱比率 & 100.0 & 65.1 & 30.7 & 20.4 & 4.8 & 8.7 & 22.2 & 10.3 & 2.9 & 7.4 \\
\hline
\end{tabular}

出所 : 埼玉県農林部食品流通課の資料より作成した。

注 : 1） 無店舗=庭先販売, 5ね売り販売, 出張販売

2) 契約 $=$ 契約販売, 特約店販売 
また，直売所等における農産物眅売実績は表 2 のよ らになっている．回答のあった都道府県についてのみ 集計すると，全体で回答5,500件，356意円となる．有 人直売所については，17都道府県で1，214件，270億円 の総販売額を持つ． 1 件（施設）当たり平均 2,224 万 円の年間売上げである.

（2）愛媛県における農産物産直, 直売所の取り組み 次に, 愛媛県を事例に農産物産直, 直売所の取り組 みの実態をみる.

愛媛県に打いて, 農家が農産物直売を日常的に開催 した始まりは1975年の松山市の生活改善グループの青 空市であった，その後，農業祭等で農家による野菜即 売が人気を呼び, 各地で生産組織, 生活改善グループ 等によって朝市，青空市等が設置されるよらになっ た.愛媛県では，これらの動きを1994年及び1998年に 調査している.

1994年調査では, 愛媛県における農産物産直, 直売 所の取り組みは，表 3 に示したようになっている．取 り組み形態別に見ると，直接取り引きと朝市・青空市
がともに30件, 直売所 25 件, 宅配・ゆらパック22件, 観光農園 7 件等であった.

また，回答事例の年間販売額は，総額 12 億円 3,425 万円である. 取り組み形態別で最も多かったのは直接 取り引きの約 4.3 億円で, 全体の $34.7 \%$ 占める. 次 いで，宅配・郵便パックが2.4億円（19.4\%）となっ ているが，他の取り引き形態も同水準の販売金額を示 している。 また年間販売金額は 1 事例平均でみて，観 光農園等の約 2,455 万円, 契約栽培による直接取り引 きが約 2,000 万円が多く, 直売所等の年間販売額は平 均800万円である.

その後も直売所等の設置数は増加し，1998年調査で は114力所と倍増して拈り，同時に多様な取り組みが 展開されるようになった。この調查結果から, 定期的 な休日のみを持つ常設的なるのを直売所とし，それ以 外のものを青空市等として集計すると, 直売所は 46 力 所, 青空市68力所となり, いずれのタイプもこの 3 4 年で倍増している（表 4 ）.

運営組織をみると, 直売所は任意組合・農家グルー

表 2. 形態別にみた農産物直売の販売金額（全国，1997年度）

\begin{tabular}{|c|c|c|c|c|c|}
\hline 形態 調査区分 & 都道府県数 & 件 数 & 総販売高 & 構成比率 & $\begin{array}{l}\text { 1件当たり } \\
\text { 販売高 }\end{array}$ \\
\hline 有店舗 & - & 3,397 & $3,209,928$ & 90.2 & 945 \\
\hline 有人直売所 & 17 & 1,214 & $2,700,294$ & 75.9 & 2,224 \\
\hline 無人直売所 & 13 & 953 & 64,972 & 1.8 & 68 \\
\hline 朝市・夕市 & 15 & 1,230 & 444,662 & 12.5 & 362 \\
\hline 無店舗 & - & 1,730 & 171,154 & 4.8 & 99 \\
\hline 契約 & - & 184 & 66,273 & 1.9 & 360 \\
\hline 宅配·宅送販売 & 8 & 189 & 110,690 & 3.1 & 586 \\
\hline 合 計 & - & 5,500 & $3,558,045$ & 100.0 & 647 \\
\hline
\end{tabular}

出所 : 前揭表 1 と同じ.

注 : 販売金額について回答のあった都道府県のみについて，件数と販売高を集計し，作成した.

表 3．取り組み形態別にみた眅売金額（愛媛県，1994年度）

\begin{tabular}{|c|c|c|c|c|c|}
\hline 取り組み形態等 & 主体 数 & 事 例 数 & 販 売 金 額 & 1 主体平均 & 1事例平均 \\
\hline 直接取り引き & 24 & 30 & 427,672 & 17,820 & 14,256 \\
\hline 契約栽培 & 9 & 11 & 220,939 & 24,549 & 20,085 \\
\hline 契約なし & 15 & 19 & 206,733 & 13,782 & 10,881 \\
\hline 朝市・青空市 & 30 & 30 & 175,639 & 5,855 & 5,855 \\
\hline 直売所等 & 16 & 25 & 199,881 & 12,493 & 7,995 \\
\hline 観光農園等 & 7 & 7 & 171,863 & 24,552 & 24,552 \\
\hline 宅配・ゆらパック & 14 & 22 & 238,894 & 17,064 & 10,859 \\
\hline その他 & 8 & 9 & 20,300 & 2,538 & 2,256 \\
\hline 合 計 & 99 & 123 & $1,234,249$ & 12,467 & 10,035 \\
\hline
\end{tabular}

注：前掲資料より集計，作成した. 
プと農業協同組合が多く両者で63を占める。これに対 して青空市等では, 農家女性を中心とした生活改善グ ループ等による運営が半数を占めている.これらの直 売所等で取扱っている商品としては, 食料品のみより も，これに花き類を加亲たタイプか，木工品等の非農 産物, 非食料品を加えたタイプのものが多い.

\section{（3）農産物直売所の実䈍}

愛媛県で設立されている農産物直売所のらち，3つ のタイプについてその実態をみる.

1）城川町特産品センターきなはい屋=小規模特産品 センタータイプ（表 $5 ， 6 ， 7 ， 9$ )

交流人口の中心である松山市から約 $90 \mathrm{~km}$ ，車で 2 時間の距離にある．1994年 4 月に設立され，産業開発

表 4. 愛媛県に括汁る農産物直売所等の現況 （1998年 3 月調査）

(1) 運営組織別

\begin{tabular}{|c|c|c|c|}
\hline 運 営 組 織 & 直売 所 & 青空市等 & 合 \\
\hline 任意組合・農家グループ & 17 & 16 & 33 \\
\hline 生活改善グループ等 & 5 & 35 & 40 \\
\hline 農業協同組合 & 12 & 5 & 17 \\
\hline 自治体 & 6 & 2 & 8 \\
\hline その他 & 6 & 10 & 16 \\
\hline 合 & 46 & 68 & 114 \\
\hline
\end{tabular}

\begin{tabular}{|c|c|c|c|}
\hline 取扱品目別 & & & 単位：件 \\
\hline 取 扱 品 目 & 直売所 & 青空市等 & 合 \\
\hline 生鮮食料品のみ & 6 & 4 & 10 \\
\hline 生鮮十加工食料品 & 7 & 13 & 20 \\
\hline 食料品+花き類 & 19 & 35 & 54 \\
\hline 食料品+非食料品 & 14 & 16 & 30 \\
\hline 計 & 46 & 68 & 114 \\
\hline
\end{tabular}

公社によって運営されている。同町の自然牧場（ハム 工場), 自然農場（農産加工場）等での特産加工品を 中心とした販売と野菜等の直売を行っている. 施設全 体としては年間 1 億円余りの売上げ実績を持つが，直 売所売上げとしては850万円と小規模である. 直売所 に出荷してくる農家は多いが，組織化がなされて拉ら ず，1 人当たり販売実績は 7 万円程度と極めて少な い. 農家番号と価格表示の札を付けているが，レジは 直売所兼用であり，交流や販売に関する情報も十分に 伝達されていない。

伝票からみる限り, 直売部門の受入金額が1,078万 円, 販売実績が850万円であることから, 平均残品率 は約 $20 \%$ と推定される．野菜の割合が高く $(48.1 \%)$ ， 次いで乾しいたけ，ヒガシイモ等の農林産物加工品が 多い. 茶・薬草の出荷が多いのも特徵である.

2) 内子町フレッシュパークからり=大規模観光立地 タイプ (表 $5,6,8,9$ ，図 1)

松山市から約 $40 \mathrm{~km}$ (1 時間) の距離にある.古い 町並みが保存されていることから，最近では全国的に 知られるよらになっている. 1994年 7 月に「内の子市 場」として直売を開始し，1996年 4 月より情報セン ター, レストラン等も併設する現在の施設が建設され た. 1997年 4 月に内子町, JA 内子, 生産農家等の出 資により株式会社を設立し，以降はこの株式会社によ って運営されている. パコン及びファクシミリと POS システムを利用した発注システム, 商品管理を 行っている，また，生産農家は多いが，組織化がなさ れておらり，直売所への交番制をとり利用者（都市消費 者）との交流による情報をキャッチしている。また，

注：愛媛県の資料より集計，作成した.

表 5. 事例とした農産物直売所

\begin{tabular}{|c|c|c|c|}
\hline 直売所名 & 城川町特産品センターきなはい屋 & 内子フレッシュパークからり & 大洲市あさぎり市 \\
\hline 設立時期 & 1994.4 .1 & 1994.7 .23 & 1991.4 .1 \\
\hline 運営形態 & 町営（産業開発公社） & 1997.4.1より株式会社(2000万円) & 出荷組合「良心市」 \\
\hline 主な施設 & $\begin{array}{l}\text { 特産品展示即売所, 野菜等直売 } \\
\text { 所, らどんレストラン, 駐車場, } \\
\text { トイレ }\end{array}$ & $\begin{array}{l}\text { 特産品直売所, 情報センター, } \\
\text { ストラン, 駐車場, トイレ }\end{array}$ & $\begin{array}{l}\text { 野菜等直売所, 駐車場, 簡易トイ } \\
\text { レ }\end{array}$ \\
\hline 休業日 & 毎週火曜日 & 正月 5 日間 & 毎週火曜日 \\
\hline $\begin{array}{l}\text { 年間売上額 } \\
\text { ( } 5 \text { ち直売所) }\end{array}$ & $\begin{array}{l}1 \text { 億 } 1,000 \text { 万円 } \\
\text { (850万円) }\end{array}$ & $\begin{array}{l}1 \text { 億 } 7,500 \text { 万円 } \\
(1 \text { 億 } 6,000 \text { 万円 })\end{array}$ & $\begin{array}{l}1 \text { 億 } 5,800 \text { 万円 } \\
\text { ( } 1 \text { 億 } 5,800 \text { 万円 })\end{array}$ \\
\hline 参加農家数 & 180名 & 221名 & 94名 \\
\hline 販売方法 & $\begin{array}{l}\text { 価格表示の番号札 } \\
\text { レジは直売所兼用 } \\
\text { レジはパート } 3 \text { 名 }\end{array}$ & $\begin{array}{l}\text { FAX で事前連絡し, バーコード } \\
\text { ・シールで POS 対応 } \\
\text { レジはパート } 6 \text { 名 }\end{array}$ & $\begin{array}{l}\text { 番号札裏のバーコードで精算対応 } \\
\text { レジはパート } 3 \text { 名 }\end{array}$ \\
\hline 手 数 料 & $10 \%$ & $15 \%$ & $11 \%$ \\
\hline
\end{tabular}

注 : 各直売所の資料及び担当者からのヒアリングから作成した. 
道の駅として町の観光拠点となり, 観光客の来訪者の 利用が多い。

表 6 ．農産物などの直売実績

単位 : 千円，\%

\begin{tabular}{|c|c|c|c|}
\hline 年度 & 城川町きなはい屋 & $\begin{array}{l}\text { 内子町フレッシュ } \\
\text { パークからり }\end{array}$ & 大洲市あさぎり市 \\
\hline 1991年 & - & - & 41,600 \\
\hline 92 & - & - & 74,100 \\
\hline 93 & - & - & 96,500 \\
\hline 94 & 5,309 & 41,769 & 126,800 \\
\hline 95 & 5,709 & 70,801 & 125,100 \\
\hline 96 & 7,267 & 109,188 & 144,400 \\
\hline 97 & 8,518 & 160,109 & 158,400 \\
\hline
\end{tabular}

注：1）各直売所の伝票などから集計，作成した.

2) いずれも開始年は途中月から.
また，果樹部門でかつてはクリとユズの産地であっ たが，現在は様相を変えている．国営農地開発におい て，ブドウ，ナシ，モモの観光農業が盛んであり，連 動して販売も行っている．したがって品目別販売金額 では果物が最も多く，全体の $40.2 \%$ 占めている．主 要品目でもこれらの果物品種の販売額が多い.

出荷者 1 人当たりの販売高は的 82 万円で, 50 万円前 後の販売高層を中心に分布しているが，300万円以上 の販売高の農家も多くみられる。

3 ) 大洲市あさぎり市＝大規模農村小売市場タイプ(表 $5,6,9)$

松山市から約 $50 \mathrm{~km}$ (1 時間10分) の距離にある. 常設直売所としては愛媛県下では比較的早い時期の

表 7 . 城川町きなはい屋の品目別受入れ金額（1997年）

\begin{tabular}{c|c|c|c|c|c|c}
\hline \hline & 野 菜 & 果 物 & 加工品 & 茶・薬草 & その他 & 計 \\
\hline 1 月 & 151 & 6 & 273 & 52 & 11 & 493 \\
2 月 & 101 & 17 & 259 & 74 & 11 & 462 \\
3 月 & 244 & 135 & 278 & 160 & 20 & 836 \\
4 月 & 351 & 112 & 268 & 137 & 27 & 895 \\
5 月 & 356 & 21 & 319 & 207 & 22 & 925 \\
6 月 & 355 & 6 & 94 & 129 & 17 & 600 \\
7 月 & 396 & 9 & 145 & 144 & 0 & 694 \\
8 月 & 626 & 64 & 175 & 173 & 23 & 1,061 \\
9 月 & 600 & 313 & 129 & 145 & 15 & 1,202 \\
10 月 & 802 & 133 & 196 & 163 & 25 & 1,320 \\
11 月 & 899 & 63 & 314 & 198 & 29 & 1,504 \\
12 月 & 307 & 20 & 320 & 107 & 38 & 793 \\
\hline 計 & 5,191 & 898 & 2,769 & 1,689 & 239 & 10,786 \\
構成比 & 48.1 & 8.3 & 25.7 & 15.7 & 2.2 & 100.0 \\
\hline
\end{tabular}

主要品目（青果物）

\begin{tabular}{|l|r|}
\hline \multicolumn{1}{|c|}{ 品目名 } & 金 額 \\
\hline 生シイタケ & 1,148 \\
乾シイタケ & 502 \\
ヤマイモ & 440 \\
クリ & 433 \\
トマト & 390 \\
イチゴ & 278 \\
キュウリ & 198 \\
サトイモ & 174 \\
ユズ & 157 \\
ダイコン & 125 \\
キャベッ & 116 \\
\hline
\end{tabular}

注 : 同施設の受入れ伝票より集計した.

表 8.フレッシュパークからりの品目別販売金額（1997年）

単位：千円，\%

\begin{tabular}{c|c|c|r|r|r|r}
\hline \hline & 野 菜 & 果 物 & 加工品 & 花き類 & \multicolumn{1}{c|}{ その他 } & \multicolumn{1}{c}{ 計 } \\
\hline 1 月 & 1,123 & 1,154 & 1,037 & 668 & 568 & 4,551 \\
2 月 & 1,529 & 1,571 & 1,411 & 910 & 774 & 6,195 \\
3 月 & 1,840 & 1,890 & 1,699 & 1,095 & 931 & 7,455 \\
4 月 & 1,831 & 1,185 & 1,713 & 772 & 4,571 & 10,071 \\
5 月 & 2,728 & 787 & 1,479 & 1,093 & 1,398 & 7,484 \\
6 月 & 3,449 & 1,307 & 1,319 & 1,116 & 1,215 & 8,405 \\
7 月 & 3,361 & 5,696 & 1,380 & 1,374 & 1,166 & 12,976 \\
8 月 & 4,644 & 18,137 & 1,580 & 2,065 & 1,672 & 28,098 \\
9 月 & 4,473 & 16,678 & 1,292 & 1,830 & 1,205 & 25,479 \\
10 月 & 6,000 & 8,531 & 2,252 & 1,070 & 1,603 & 19,456 \\
11 月 & 4,490 & 3,236 & 2,761 & 1,346 & 1,773 & 14,057 \\
12 月 & 3,606 & 3,703 & 3,328 & 2,145 & 1,825 & 14,607 \\
\hline 計 & 39,525 & 63,873 & 21,251 & 15,484 & 18,701 & 158,835 \\
構成比 & 24.9 & 40.2 & 13.4 & 9.7 & 11.8 & 100.0 \\
\hline
\end{tabular}

主要品目（青果物）

\begin{tabular}{|l|r|}
\hline 品目 名 & \multicolumn{1}{c|}{ 金額 } \\
\hline ピオーネ & 12,903 \\
モモ & 10,174 \\
幸水 & 5,444 \\
ハーブ & 5,382 \\
トマト & 3,844 \\
巨峰 & 3,796 \\
キュウリ & 3,517 \\
イチゴ & 3,454 \\
梨 & 3,390 \\
豊水 & 3,340 \\
乾シイタケ & 3,076 \\
クリ & 2,915 \\
生シイタケ & 2,842 \\
スイカ & 2,444 \\
\hline
\end{tabular}

注 : 同施設の受入れ伝票より集計した。一部の月はデータ久損のため推計している 
表 9. 各直売所の個人別販売高の分布（1997年度）

\begin{tabular}{|c|c|c|c|c|c|c|}
\hline \multirow{2}{*}{ 販 売 高 } & \multicolumn{2}{|c|}{ きなはい屋 } & \multicolumn{2}{|c|}{ フレッシュパークからり } & \multicolumn{2}{|c|}{ あさぎり市 } \\
\hline & 農 家 数 & 比率 & 農 家 数 & 比率 & 農 家 数 & 比率 \\
\hline 500万円以上 & - & - & 2 & 1.0 & 3 & 3.3 \\
\hline $300 \sim 500$ 万円 & - & - & 11 & 5.7 & 17 & 18.9 \\
\hline $100 \sim 300$ 万円 & 1 & 0.9 & 31 & 16.0 & 30 & 33.3 \\
\hline $50 \sim 100$ 万円 & - & - & 33 & 17.0 & 17 & 18.9 \\
\hline $30 \sim 50$ 万円 & 6 & 5.3 & 36 & 18.6 & 15 & 16.7 \\
\hline $10 \sim 30$ 万円 & 16 & 14.0 & 35 & 18.0 & 3 & 3.3 \\
\hline 5～10万円 & 18 & 15.8 & 14 & 7.2 & 3 & 3.3 \\
\hline 5 万円未満 & 73 & 64.0 & 32 & 16.5 & 2 & 2.2 \\
\hline $\begin{array}{c}\text { 計 } \\
\text { 平均（千円） }\end{array}$ & $\begin{array}{r}114 \\
71\end{array}$ & $\begin{array}{c}100.0 \\
-\end{array}$ & $\begin{array}{l}194 \\
819 \\
\end{array}$ & $\begin{array}{c}100.0 \\
-\end{array}$ & $\begin{array}{r}90 \\
1,760 \\
\end{array}$ & $\begin{array}{c}100.0 \\
-\end{array}$ \\
\hline $\begin{array}{l}\text { 登録者数 } \\
\text { 実績な し }\end{array}$ & $\begin{array}{r}180 \\
66\end{array}$ & $\begin{array}{l}- \\
36.7\end{array}$ & $\begin{array}{r}221 \\
27\end{array}$ & $\overline{12.2}$ & $\begin{array}{r}94 \\
4\end{array}$ & $\overline{4.3}$ \\
\hline
\end{tabular}

注 : 各直売所の資料などから集計した.

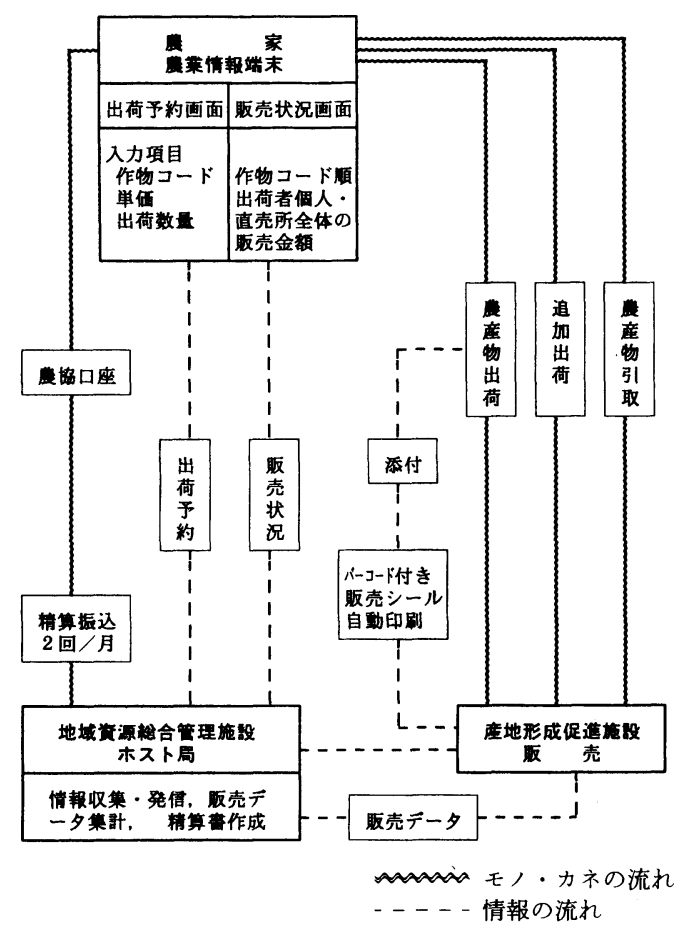

図 1 、農家農業情報端末を利用した出荷情報フローチ 十ート

注：内子町フレッシュパークからりの資料より作成した.

1991年 4 月に設立され, 市内の野菜生産農家が出荷組 合「良心市」を設立し, 運営している. 商品には農家 番号札に価格が書かれいるが，その裏のバーュードで 同様の情報がレジで入力され，売上げ精算に対応して いる. 事務局は大洲農協が行っている. $11 \%$ 手数料 のらち $2 \%$ 相当分を事務局経費として支出している.
なお，品目別に管理していないため正確には把握でき ないが, 総販売高に占める野菜の比率は $70 \%$ 強と推定 される。

出荷者の多くは壮年層の野菜生産農家で, 200万円 前後の販売高層の農家が多く，1農家平均販売高は 176万円と高いものとなっている.ささらに，この直売 所以外に農協共販, 個人市場出荷等を合わせて行ら大 規模野菜専業農家の存在も見受けられる.「都市・農 村交流はレジ担当の専従職員に任せて」おり, 農家は 野菜生産と出荷に専念することになる.

\section{5. 農産物産直, 直売所の意義, 問題点}

このように, 農産物産直, 直売所の設立, 増加の背 景と最近の全国及び愛媛県の取り組み実態をみてき た. 個別差が大きく存在するが，いずれの場合も生産 者, 消費者等にとって意義を持つ活動となっている.

生産者からみた農産物直売所の意義として次の 4 点 が上げられる。

第 1 に，新しい流通チャネルを獲得できたことであ る.

第 2 に, 対面販売による情報の直接獲得によって, 消費者ニーズの把握をし, 売れるものを生産し販売す るといら主体性と自覚を促していることである.

第 3 に, 規格外品でも一定需要量の確保ができるこ とから, 兼業農家や高龄者・女性農業者の活躍の場と なり得たことである.

第 4 に，従来の卸売市場流通に対して流通コストを 低減し，一部ではあるが価格的にも競争力を持つよう になったことである。

利用者である消費者への効果も大きい，消費者から 
みた農産物直売所の意義として,

第 1 に, 農産物の持つ季節性, 「旬」等商品の知識 を広げることができたことである．生産者側からの情 報発信がなされるよらになった。

第 2 に，逆に消費者側からの受信も可能となった。 対面販売等を通じて消費者自らのニーズを生産者に质 達することが可能となったことである.

第 3 に, 生産と消費の同時性の実現によって, 都市 部のスーパーマーケットでの購入農産物との製品差別 化が可能となった.

等があげられる，そして，地域産業への波及効果も大 きい。

その第 1 として，直売所での販売に対応した特産品 加工部門を増設する動きが活発になった。

第 2 に，増加，長期滞在寸る観光客への対応が容易 になっている。

第 3 に，これらを通じて，地域内他産業の振興と産 業間連携が図られるよらになった。

ただし，農産物直売所には，大きく分けて 2 つ問 題点が存在すると考兄られる。

第 1 は，中心商品である生鮮農産物が，本来強い季 節性，気候に左右されやすい商品特性を持つことであ る. 農産物直売所の場合, 生産者, 供給者が狭い地域 にいるため，その生産物は気候に左右されやすく，季 節商品とならざるをえない。

第 2 は，他店との差別化が難しいことであり，地域 によっては農産物直売所の林立状況で, 施設間の競合 が強まっていることである．農産物直売所の取り組み が進むと，現在ではその競合が問題となっている．競 合には地域内（市町村内）の競合と広域圏での競合が 存在するが，新しい施設ができるたびに客足が減ると いらケースもある.

\section{6. むすび}

以上みてきたように，従来の大都市卸売市場中心に 向けられる流通形態では, 従来型の産直の場合も含め て, 農村から農産物が都市へ流れ, 消費者は購入し, 消費する形態であった．市場は都市部で卸売，加工， 小売と段階的な市場が形成され，価格形成は卸売市場 でなされるが，量眅店の価格形成への影響力は大き い. 生産者はプライステーカー（価格受容者）となら ざるをえない，その結果，過当な産地間の価格競争が 展開し，それは輸入農産物との競争へと結びつつあ る. 近年生ずる価格破壊は，都市と農村の関係を共生 関係から再び対立関係へと向ける.
本来農産物の流通は，身近な都市と農村の間で共生 的な関係の中で成立してきたものである．その中で， 可能な限り循環的な経済システムが自成していた。し かし，大きな社会，流通への転換以降，モノは農村か ら都市へ流れ，そこで消費された後に循環することが なくなっている，カネも都市内部で滞留するだけで， 農村で再生産可能なものが戻ってこなくなった。

共生的な関係を成立し得る，身近な都市と農村の 間，地域内でのモノ，ヒト，カネの循環システムとし ての流通形態を構築することが必要となっている。そ の意味で，近年の市場外流通の取り組みは，その方向 の妥当性を物語るとともに克服すべき問題点を提示し ている. 前述した直売所, 朝市・青空市タイプの農産 物直売, 産直の現代的特徵は, 都市消費者が農村に来 て，農産物を購入し，消費する農村小売市場の誕生で あり，生産と消費の同時性の形成である．価格形成へ 生産者が直接参加することから，生産者はプライス メーカー（価格決定者）となったのである.

ただし，直売所は十分な品揃えが農家によって成り 立ち，始めて営業ができる．しかし，季節的に品揃え が薄くなる冬場等は，対策を考えなければならない。 そのために，生産者グループの組織化の必要性があげ られる. 同時に，特色ある農産物と加工品の開発・販 売が求められている.

一部地域で林立状況がみられるものの，これら農産 物直売所はまだ発展途上と考劣られる。単独の直売所 では，その利用者は通過人口である観光客あるいは都 市住民の往復中心となる。「道の駅」等に設置された 農産物直売所を連結することで，これら直売所を点と しての利用ではなく，線あるいは面としての利用に結 びつけ，、リピーターの形成を図るべきであろう。

そして前述したよらに，地域産業への波及効果は大 きい，直売所に向けた特産品の加工や観光客への対応 を通じて地域内他産業の振興と産業間連携が図られて いる．さらに，農産物直売所や特産品センターを建設 する際の費用支出や雇用創出の促進等によって，地域 での経済効果が高まり，Uターン者，Iターン者の受 け皿となりらる，地域資源の再評価を進めることで， 地域の活性化やイメージアップを図ることができる。

注 1）農産物直売施設の呼称として，「フォーマーズマーケ ット」が用いられることがある. しかし，この場合ど のレベルの施設を指すかについて混乱がみられる.農 協が運営する施設に限定する論者が多いため，本報告 ではこの呼称は用いない。 
2）その第 1 は，現実の中央卸売市場を中心とする卸売市 場体系の下で, 産直による経済的メリットの発生とそ の獲得を重視していく型で，「価值実現獲得型」であ り，事業論的な協同組合間提㧞にもとつく産直であ る. 第 2 は, 生産者と消費者の結びつきによって付加 価値をより重視し，その獲得を重視していく型で, 「使用価値充実型」であり，運動論的な協同組合間提 擭にもとつく産直である. 岡部守『産直と農協』（日 本経済評論社, 1980年) 参照.

3）朝の営業に限定せず直売施設全般を集計している.な 扣一部データのない都道府県が存在する. 農林水産省 婦人・生活課『全国朝市実施状況一覧表』(1995年) 参照.

4） 4 都道府県の回答が得られていない.
5）なお取り組み主体別に見ると，生活改善・婦人・農産 加エグループの場合は朝市・青空市が，農業協同組合 の場合は宅配・郵便パックが，生産者グルーブの場合 は直接取り引きが多くなっている.

6）国道56号線中山町，内子町から国道197号線沿線にか けて設置された農産物直売所群に対して, 松山市等の 都市住民が生鮮農産物等地域特産品をりピーターとし て㲘入している.なお，このルートを中川聰七郎及び 筆者は「ふるさと街道」と呼称し、リピーターとなる 観光客を獲得することからも，今後展開方向を検討す べきことを訴えている．中川聰七郎『農政改革の課題』 (農林統計協会，1997年），第12章を参照.なお，山 口県ではその動きを支援する「ルートフェスタ」を開 催している.

（䇧者：愛媛大学貫学部） 